\title{
Yurisdiksi Kriminal Terhadap Black Flight Di Ruang Udara Wilayah Indonesia
}

\author{
Candra Ulfatun Nisa ${ }^{1}$, Hari Sutra Disemadi ${ }^{2 *}$ \\ 1, 2,Fakultas Hukum Universitas Diponegoro, Semarang, Indonesia \\ *E-mail: haridisemadi@gmail.com
}

Dikirim: 07/06/2020

\begin{tabular}{l}
\hline Info Artikel \\
\hline Keywords: \\
Black Flight; \\
Criminal Jurisdiction; \\
Sovereignty. \\
\\
Kata Kunci: \\
Black Flight; \\
Yurisdiksi Kriminal; \\
Kedaulatan.
\end{tabular}

Direvisi: 30/08/2020

Dipublikasi: 07/09/2020

Abstract

The state in its capacity as one of the subjects of international law, has the rights and obligations associated with sovereignty. The state is free and independent to exercise its sovereignty rights in full but also has an obligation to pay attention to its limits in not exercising its sovereignty in the territory of other countries. Regarding the sovereignty of the territory of the Republic of Indonesia, even though it has clearly established its boundaries and has been recognized by international law, violations of sovereignty territories often occur that are not intentional or intentional to achieve certain goals. One of them is a violation of the sovereignty of Indonesian airspace, namely black flight. The method of research using the normative juridical approach, with descriptive research specifications. The results of this study are that Indonesia's sovereignty over its national airspace boundaries is full, exclusive and fully closed to foreign aircraft or aircraft belonging to other countries. With regard to black flight, Indonesia by TNI-AU carries out criminal jurisdiction with a lighter action preceded in the form of a warning to get out and immediately leave the Indonesian airspace, to the more severe act of forcing a landing.

\begin{tabular}{l}
\hline Abstrak \\
\hline Negara dalam kapasitasnya sebagai salah satu subjek hukum \\
internasional memiliki hak dan kewajiban yang berkaitan dengan \\
kedaulatan. Negara bebas dan merdeka untuk menjalankan hak \\
kedaulatannya secara penuh tetapi juga berkewajiban memperhatikan \\
batas-batasnya untuk tidak menjalankan kedaulatannya di wilayah \\
negara lain. Mengenai kedaulatan wilayah Negara Kesatuan Republik \\
Indonesia, meskipun telah ditetapkan secara jelas batas-batasnya dan \\
telah diakui oleh hukum internasional, seringkali terjadi pelanggaran \\
wilayah kedaulatan yang tidak disengaja atau disengaja untuk mencapai \\
tujuan tertentu. Salah satunya pelanggaran kedaulatan wilayah udara \\
Indonesia yaitu black flight. Metode penelitian menggunakan \\
pendekatan yuridis normatif, dengan spesifikasi penelitian deskriptif. \\
Hasil penelitian ini adalah bahwa kedaulatan Indonesia atas batas \\
wilayah udara nasionalnya bersifat penuh, eksklusif dan tertutup
\end{tabular}


DOI:

10.47268/sasi.v26i3.289 sepenuhnya bagi pesawat atau pesawat asing milik negara lain. Terkait black flight, Indonesia oleh TNI-AU menjalankan yurisdiksi pidana dengan tindakan yang lebih ringan diawali berupa peringatan untuk keluar dan segera meninggalkan wilayah udara Indonesia, hingga tindakan yang lebih berat yaitu memaksa pendaratan.

\section{A. PENDAHULUAN}

Berbicara perihal lingkup hukum Internasional, khususnya mengenai subjek hukum, Negara dapat dikatakan mempunyai kedudukan selaku subjek hukum yang paling utama apabila dibandingkan dengan keberadaan subjek-subjek hukum Internasional selain daripadanya. Berkenaan dengan kedudukannya selaku subjek hukum, lazimnya tentu saja tiap Negara mempunyai peran sebagai pengemban sekaligus pemelihara hak dan kewajiban yang telah ditetapkan menurut hukum yakni perihal mampu untuk menyelenggarakan relasi terkait hukum bersama-sama dengan sesama pengemban sekaligus pemelihara hak dan kewajiban hukum yang lainnya. ${ }^{1}$ Dari sisi hukum Internasional, Negara mempunyai hak untuk menambatkan dirinya sendiri selaku subjek hukum secara pribadi ke dalam suatu perjanjian internasional, untuk memanfaatkan hak-hak yang dimiliki berdasarkan ketentuan hukum Internsional serta memanfaatkan pula hak istimewa yang diberikan terkait hak imunitas yakni kekebalan diplomatik.

Mengingat kedudukannya selaku subjek hukum Internasional, sudah patutlah bahwa dalam kapasitasnya, tiap Negara mempunyai berbagai hak dasar di samping pula mempunyai suatu kewajiban mutlak yang telah ditentukan secara tegas dan disepakati oleh hukum Internasional secara umum. Hak yang demikian ini merupakan suatu hal yang disebut dengan kedaulatan. ${ }^{2}$ Sebuah kedaulatan yang dimiliki kaitannya dalam suatu keterikatan antar Negara satu dengan Negara yang lainnya menegaskan bahwa pada dasarnya Negara bersifat bebas dan merdeka dalam menerapkan hak-hak kedaulatan yang dimiliki agar tetap terjaga dan bisa menjalankan fungsi-fungsi Negara yakni dalam hal menjalankan pemerintahannya tanpa intervensi dari Negara lainnya sesuai dengan aturan undang-undang, sekaligus pula memberi batasan untuk menjauhkan diri dari adanya ancaman dan gangguan yang kemungkinan bisa datang dari Negara lainnya. ${ }^{3}$

Selain itu, kedaulatan yang menjadi hak tiap Negara difungsikan untuk menegaskan mengenai kebenaran bahwa sesungguhnya di dalam sebuah Negara benar-benar mengakui adanya kekuasaan tertinggi. Sehingga kedaulatan suatu Negara yang dimiliki pada dasarnya bersifat mutlak dan wajib untuk dijaga sepenuhnya oleh seluruh komponen Negara sekalipun oleh masyarakat suatu Negara itu sendiri demi untuk menjunjung tinggi harkat dan martabat suatu Negara.

Secara otomatis, seperti yang telah dijabarkan di atas, selain mamanfaatkan hak-hak yang dimilikinya, Negara pun mengemban suatu kewajiban pula yakni untuk tidak menjalankan suatu kedaulatannya di wilayah negara lain dan berkewajiban untuk menghindari tindakan yang tujuannya mengintervensi khususnya terhadap persoalan atau perkara milik Negara lain. Sehingga dalam hal ini, suatu Negara tidaklah mungkin dapat

1 Yulianingsih, W., \& Sholihin, M.F. (2014). Hukum Organisasi Internasional, Yogyakarta: Penerbit Andi, h. 4.

2 Riyanto, S. (2012). "Kedaulatan Negara Dalam Kerangka Hukum Internasional Kontemporer”. Yustisia Jurnal Hukum, 1(3): 5-14, DOI: https://doi.org/10.20961/yustisia.v1i3.10074, h. 7.

3 Loc. Cit. 
memanfaatkan hak-hak yang dimilikinya dengan tidak memberikan pengakuam dan penghormatan atas segala hak-hak yang dipunyai oleh Negara lainnya. ${ }^{4}$ Prinsip dasar ini selaras dengan opini yang diberikan Mochtar Kusumaatmadja, yakni pada dasarnya sebuah kedaulatan merupakan sifat dasar yang melekat dan sebuah ciri yang dimiliki oleh suatu Negara, yang mana sekalipun suatu Negara memiliki kedaulatan secara penuh, tetap harus memperhatikan batas-batas yang ada. Sehingga keberlakuan kedaulatan tiap Negara benarbenar hanya terbatas cakupannya pada wilayah suatu Negara itu sendiri, secara otomatis itu berarti menunjukkan bahwa diluar wilayah suatu Negara yang bersangkutan, Negara tersebut tidak lagi berhak atas kedaulatannya yang dimaksudkan. ${ }^{5}$

Suatu kedaulatan tidak hanya terbatas pada kedaulatan yang dimiliki oleh sesama Negara lainnya, tetapi juga terbatas pada keharusan suatu Negara untuk menundukkan dirinya secara hukum pada hukum internasional sehingga dalam hal ini, hak kedaulatan dipandang bukan lagi sebagai sesuatu yang menyeluruh secara bulat dan sepenuhnya utuh. Inilah yang dikatakan bahwa kedaulatan yang dimilki oleh suatu negara tidak selalu mempunyai sifat yang mutlak (absolute) tetapi justru mempunyai sifat yang relatif (Relative) untuk tetap memberikan penghormatan atas hak kedaulatan maupun atas kesatuan suatu wilaayah negara lain dalam batas-batas tertentu yang telah diputuskan dalam hukum Internasional dan untuk dapat berhati-hati agar tidak mengambil tindakan yang melanggar dan menimbulkan kerugian bagi Negara lain. ${ }^{6}$

Berdasarkan Pasal 1 Konvensi Montevidio 1933 yang mengatur perihal hak-hak serta perihal kewajiban-kewajiban yang dimiliki oleh tiap Negara, Negara dalam lingkup hukum Internsional sebagai subjek hukum haruslah memenuhi syarat-syarat yang salah satunya harus mempunyai wilayah tertentu. Bahkan muncul pernyataan yang sudah tidak asing lagi yakni bahwa tidak akan ada negara tanpa wilayah. Secara gamblang, hukum Internasional tidak mengatur mengenai ketentuan dan batas luas wilayah yang harus dimiliki untuk dapat disebut sebagai suatu Negara. Tetapi, secara jelas, wilayah yang dimaksudkan tidak harus dalam satu kesatuan atau dalam hal ini wilayah dapat pula meliputi bagian-bagian yang terletak di kawasan-kawasan yang berlainan baik sebagai landasan material maupun landasan fisik yang ditetapkan suatu negara. Sehingga wilayah suatu Negara tidak hanya mencakup wilayah dalam arti sempit yakni lingkup geografis saja, tetapi juga wilayah dalam arti luas yakni sebagai suatu ruang untuk dapat melaksanakan yurisdiksinya secara penuh sebagai suatu Negara. ${ }^{7}$

Menurut hukum Internasional, kedaulatan suatu negara terbagi dalam 3 (tiga), yakni antara lain meliputi adanya wilayah darat, adanya wilayah laut dan atau perairan dan adanya wilayah udara. ${ }^{8}$ Indonesia pun mengatur hal yang sama mengenai pembagian wilayah Negara yang diatur dalam Pasal 4 Undang-Undang Nomor 43 Tahun2008 Tentang Wilayah Negara, yakni wilayah Negara merupakan keutuhan wujud yang satu kesatuan tak terpisah yang mencakup wilayah daratan, wilayah perairan yang merupakan perairan pedalaman, kepulauan maupun wilayah laut teritorial beserta dasar laut dan tanah yang tepat berada dibawahnya, dan juga ruang udara yang tepat berada diatasnya, termasuk pula segala sesuatu

4 Sitepu, P. A. (2011). Studi Hubungan Internasional, Yogyakarta: Graha Ilmu, h. 124.

5 Kusumaatmadja, M. (2010). Pengantar Hukum Internasional: Buku I Bagian Umum, Jakarta: Bina Cipta, h. 7.

${ }^{6}$ Hadiwijoyo, S. S. (2011). Perbatasan Negara Dalam Dimensi Hukum Internasional, Yogyakarta: Graha Ilmu, h. 8.

7 Sitepu, P.A. (2011). Op. Cit., h. 129.

8 Barus, Y. J., Arif, A., \& Sutiarnoto, S. (2014). "Yurisdiksi Wilayah Udara Suatu Negara Dalam Perspektif Hukum Internasional". Sumatra Journal of International Law, 2 (1): 1-23, Retrived https://media.neliti.com/media/publications/164433-ID-none.pdf, h. 19. 
yang bernilai kekayaan yang bersumber dan tersimpan di dalam cakupan wilayahwilayahnya. Hal ini menyangkut kedaulatan suatu Negara dalam aspek teritorial yang sifat kepemilikannya oleh suatu Negara dipandang penuh dan eksklusif terhadap masyarakat dan segala benda sebagai kekayaan yang ada di dalam wilayah suatu Negara tersebut. ${ }^{9}$

Kaitannya mengenai kedaulatan wilayah suatu Negara, meskipun suatu negara telah menetapkan batas wilayahnya secara jelas dan sudah memiliki pengakuan yang dihasilkan dari prosedur yang ditetapkan hukum internasional, tetapi seringkali muncul pelanggaran terhadap batas wilayah yang terkadang sifatnya tidak hanya dilakukan secara sengaja saja, tetapi juga dilakukan dengan disengaja untuk mencapai tujuan tertentu. Salah satunya yakni adanya pelanggaran di wilayah ruang udara (Aerial Intrusion) terhadap kedaulatan wilayah udara yang bentuknya berupa penerbangan gelap (black flight). Black flight seringkali dilakukan dengan alasan yang bervariasi, antara lain untuk mencegah timbulnya biaya operasional (operating expenses) yang harus dikeluarkan, mengecek kapasitas sebuah radar dan mengecek kewaspadaan dan kesiapsiagaan terhadap defensi nasional, sampai-sampai membuat Negara Indonesia lengah dalam hal politiknya di ranah Internasional yang tujuannya sebagai ancaman yang jelas-jelas akan berakibat terhadap keamanan wilayah udara Indonesia. ${ }^{10}$ Pelanggaran di wilayah ruang udara dengan bentuk seperti ini tentu saja tidak dapat diterima dan dimaafkan dengan alasan apapun

\section{B. METODE PENELITIAN}

Penelitian ini bersifat yuridis normatif, dengan spesifikasi penelitian deskriptif. Data sekunder yang dikumpulkan dari bahan hukum primer, baik berupa ketentuan peraturan perundang-undangan dan pelaksanaannya; bahan hukum sekunder maupun bahan hukum tersier yang dilakukan melalui studi kepustakaan. Penulisan ini menggunakan metode kualitatif, yaitu menguraikan data dalam bentuk kalimat yang teratur, runtun, logis, tidak tumpang tindih dan efektif dan kemudian dilakukan pembahasan. Berdasarkan hasil pembahasan diambil kesimpulan secara deduktif sebagai jawaban terhadap permasalahan yang diteliti, yaitu mengambil kesimpulan dari yang bersifat umum kepada hal-hal yang bersifat khusus.

\section{PEMBAHASAN}

\section{Kedaulatan Negara Indonesia Atas Batas Wilayah Ruang Udara}

Setiap negara kapasitasnya selaku subjek hukum, pada dasarnya memiliki kedaulatan yang bersifat utuh menyeluruh dan juga bersifat penuh (complete dan exclusive) di ruang udara di atas wilayah teritorial negaranya masing-masing. ${ }^{11}$ Dalam lingkup hak kedaulatan suatu Negara terutama di ruang udara nasionalnya, sifat utuh menyeluruh dan sifat penuh (complete dan exclusive) yang dimaksudkan mempunyai arti yang berbeda dengan sifat yang ada di dalam lingkup kedaulatan negara di wilayah laut. Itu berarti dengan adanya sifat sedemikian rupa, maka dalam wilayah ruang udara nasional tidak mengenal dan tidak mengakui mengenai adanya istilah hak lintasan damai (innocent passage) yang umumnya

9 Daming, S. (2014). "Telaah Perwujudan Kedaulatan Negara Atas Wilayah Udara Dalam Persfektif Hukum". Yustisi, 1 (2), 23-41, Retrived http://150.107.142.43/index.php/YUSTISI/article/view/1091, h 37.

10 Yudhistira, A. (2018). "Over-the-Horizon Radar (Othr) Untuk Menjaga Wilayah Udara Dan Laut Indonesia”. Jurnal Pertahanan \& Bela Negara, 5 (2): 133-148, DOI: http://dx.doi.org/10.33172/jpbh.v5i2.361, h. 136.

11 Mangku, D. G. S., \& Radiasta, I. K. (2019). “Tanggung Jawab Negara terhadap Penembakan Pesawat MH17 berdasarkan Hukum Internasional”. Pandecta: Research Law Journal, 14 (1), 25-33, DOI: https://doi.org/10.15294/pandecta.v14i1.18987, h. 27. 
tersedia bagi pihak asing sebagaimana yang terdapat di wilayah laut teritorial suatu negara. ${ }^{12}$

Wilayah udara di dalam suatu negara merupakan ruang udara yang sifatnya satu kesatuan secara geografis disertai pula semua unsur yang terikat di dalamnya, yang mengenai batas-batas dan strukturnya telah dipastikan keseluruhannya berdasarkan aspek administratif dan atau aspek fungsional yang eksistensinya meliputi tepat di atas permukaan wilayah laut pedalaman, wilayah darat, laut teritorial dan termasuk pula wilayah laut suatu negara kepulauan. ${ }^{13}$ Pasal 1 angka 2 Undang-Undang Nomor 1 tahun 2009 Tentang Penerbangan (UU Penerbangan) pun mengatur mengenai hal yang sama, yakni menetapkan bahwa wilayah udara Indonesia mutlak merupakan wilayah dengan hak kedaulatan udara yang tepat sesuai di atas wilayah permukaan daratan dan permukaan perairan Indonesia.

Batas wilayah udara yang dikenal menurut hukum internasional terbagi atas 2 (dua) bagian yakni batas wilayah udara secara horizontal dan juga batas wilayah udara secara vertikal. Mengenai ini, Indonesia menunjukkan eksistensinya sebagai Negara yang berdaulat dengan menggunakan haknya untuk menetapkan batas jangkauan ketinggian ruang udara yang terdiri atas sampai mana untuk dapat dikategorikan sebagai batas wilayah secara vertikal dan sampai mana untuk dapat dikategorikan sebagai batas wilayah secara horizontal di ruang udara, mengingat wilayah ruang udara juga merupakan salah satu bagian dari Negara Kesatuan Republik Indonesia. ${ }^{14}$ Batas wilayah udara secara horizontal ditetapkan dengan berpatokan pada perjanjian yang telah dibentuk untuk kemudian disetujui dan ditaati bersama oleh Negara-negara tetangga yang letaknya berada di perbatasan Negara yang bersangkutan, sehingga batas wilayah udara Negara secara horizontal otomatis mengikuti batas-batas yang sesuai dengan wilayah batas dari ruang darat dan wilayah batas ruang laut. Negara Indonesia berkedaulatan mutlak atas ruang udaranya yang letaknya di atas permukaan daratan dan permukaan air hingga mencapai laut teritorialnya, sehingga dapat dikatakan bahwa batas wilayah udara Indonesia secara horizontal meliputi wilayah di atas permukaan darat, laut territorial hingga kejauhan mencapai 12 mil, di atas permukaan air di wilayah kepulauan yakni laut-laut yang letaknya dekat antara pulau-pulau yang ada di Indonesia dan di atas permukaan air pedalaman. Disamping itu, Indonesia berhak atas wilayah yurisdiksi yakni zona tambahan melalui pengukuran dari garis laut teritorial yang ketentuan kejauhannya mencapai paling banyak hingga 24 mil, zona ekonomi eksklusif yang kejauhannya mencapai 200 mil dan landas kontinen yang kejauhannya tidak sampai mencapai hingga ukuran 350 mil laut. Namun secara khusus mengenai wilayah ruang udara yang berada di atas permukaan zona tambahan, di atas permukaan zona ekonomi eksklusif dan di atas permukaan landas kontinen tidak lagi menjadi hak kedaulatan milik Negara Indonesia. Hal ini dikarenakan ruang udara yang berada di atas laut lepas merupakan kepunyaan seluruh umat manusia di dunia dan wilayah udaranya bersifat bebas meskipun dari sisi aspek wilayah udara, Indonesia dinilai yang paling mempunyai kepentingan terutama dilihat dari aspek ekonomi. Sedangkan batas kedaulatan negara atas ruang udara secara vertical, sejak dulu hingga sekarang tidak ada ketentuan yang tegas, dikarenakan persetujuan mengenai hingga batas mana ketinggian ruang udara dan sekaligus belum

12 Clorinda, J. I. U., Santoso, M. I., \& Widodo, H. (2019). "Pelanggaran Hak Lintas Navigasi Oleh Pesawat Asing Di Ruang Udara Teritorial Indonesia". Krisna Law, 1 (3), 77-86, Retrived http://fhunkris.com/journal/index.php/krisnalaw/article/view/69, h. 80.

13 Ciptantri, S. B., Mangku, D. G. S., \& Yuliartini, N. P. R. (2020). "Pertanggungjawaban Negara Uni Soviet Atas Penembakan Pesawat Korea Air Lines Ditinjau Dari Perspektif Hukum Udara Internasional". Jurnal Komunitas Yustisia, 1 (3): 41-50, h. 1.

14 Batubuaja, V. T. P. (2016). "Penataan Ruang Di Indonesia Dilihat Dari Aspek Pengusaan Ruang Udara Menurut Peraturan Pemerintah Nomor 26 Tahun 2008 Tentang Rencana Tata Ruang Wilayah Nasional". Lex Et Societatis, 4 (2.1): 87-93, h. 90. 
adanya persetujaun mengenai dari batas ketinggian berapa ruang angkasa dimulai. ${ }^{15}$

Berdasarkan pepatah bangsa Romawi, suatu Negara mempunyai kedaulatan di ruang udaranya yang batasnya hingga mencapai ketinggian yang tidak terbatas (cujus est solum eust ad coelum). Prinsip mengenai batas kedaulatan Negara di ruang udara hingga mencapai ketinggian yang batasnya hingga tak terbatas, saat ini dianggap sudah tidak lagi relevan mengingat adanya perkembangan di bidang teknologi yang contohnya dalam hal peletakan satelit-satelit yang diluncurkan ke ruang angkasa. Aturan mengenai wilayah ruang udara dan wilayah ruang angkasa dinilai sebagai sesuatu yang masih bersifat mutakhir apabila membandingkannya dengan aturan Internasional lainnya yang ada di wilayah bumi khususnya dalam hal ini aturan mengenai laut. Merupakan sesuatu yang wajar, karena pada waktu terdahulu tidak pernah terbesit bahwa benda-benda seperti roket maupun makhluk hidup khususnya manusia akan dapat menjangkau bulan dan benda-benda angkasa lainnya. Akan berbeda apabila dibandingkan dengan laut yang memang pada dasarnya telah sukses dikuasai oleh sebagian besar manusia yang mulai dilakukan berabad-abad tahun sebelumnya. ${ }^{16}$

Bertepatan dengan bertambahnya waktu dan semakin unggulnya kemajuan teknologi, memunculkan aturan lebih lanjut mengenai ruang udara yang bertujuan untuk mengontrol berbagai hal yang kemungkinan dapat terjadi pada ruang udara, yakni di dalam Pasal 1 Konvensi Paris 1919 yang menegaskan bahwa masing-masing tiap Negara menghormati segala hal menyangkut kepemilikan hak kedaulatan mutlak yang penuh dan eksklusif kepunyaan Negara lainnya, atas ruang udara yang berada tepat diatas wilayahnya. Kemudian pada perkembangannya, Konvensi Chicago 1944 pun mengusung prinsip pokok yang sama sebagaimana yang terdapat dalam Konvensi Paris 1919 tersebut sekaligus menguatkan, yakni pada dasarnya hak kedaulatan kepunyaan tiap-tiap negara bersifat utuh dan penuh (complete and exclusive) atas ruang udara wilayah kedaulatannya. Penjabaran pasal berikut memberi pemikiran bahwa bentuk konkretisasi dari adanya kedaulatan yang bersifat utuh dan penuh (complete and exclusive) atas ruang udara diatas wilayah teritorialnya, adalah: ${ }^{17}$

a) Tiap-tiap Negara masing-masing berhak untuk menjalankan dan mengontrol ruang udara nasioanlnya secara utuh dan penuh; dan

b) Tidak boleh ada sama sekali suatu aktifitas maupun upaya yang dilakukan di atas ruang udara nasional apabila tidak memperoleh izin terlebih dahulu atau seperti halnya yang telah ditetapkan dan dituliskan dalam perjanjian udara yang sifatnya bilateral maupun multilateral yang dilakukan antara satu negara dengan negara lainnya.

Konvensi-konvensi yang ada, pada pokoknya mengatur mengenai hal yang sama, yakni menegaskan bahwa Negara-negara anggota secara umum menghormati adanya kedaulatan yang dimiliki Negara lain terhadap seluruh bagian wilayah khususnya wilayah ruang udara yang bersifat utuh menyeluruh dan juga bersifat penuh. Pun sejalan dengan pendapat Bin Cheng, yang menyatakan bahwa pada umumnya tiap-tiap negara berdaulat secara penuh dan eksklusif atas wilayah udara di atas permukaan wilayahnya. Penuh dan eksklusif yang dimaksudkan berfungsi sebagai penegasan bahwasanya kedaulatan milik suatu negara terhadap ruang udaranya sangat besar, sehingga suatu Negara mempunyai yurisdiksi yang bersifat eksklusif dan mempunyai kekuasaan secara penuh untuk

15 Sefriani, S. (2015). "Pelanggaran Ruang Udara oleh Pesawat Asing Menurut Hukum Internasional dan Hukum Nasional Indonesia”. Jurnal Hukum Ius Quia Iustum, 22 (4): 538-565, DOI: https://doi.org/10.20885/iustum.vol22.iss4.art2, h. 541.

16 Sefriani, S. (2016). Hukum Internasional Suatu Pengantar Edisi Kedua, Jakarta: Raja Grafindo Persada, h. 192.

17 Mangku, D. G. S., \& Radiasta, I. K. (2019). Op. Cit., h. 28. 
memanfaatkan dan mengelola seluruh bagian wilayahnya khususnya wilayah ruang udara. ${ }^{18}$ Hak kedaulatann yang dimiliki tiap-tiap Negara atas wilayah ruang udara dianggap sebagai tumpuan untuk mengurus sebagian besar masalah hukum internasional, terutama dalam hal keberangkatan pesawat baik datangnya pesawat maupun perginya pesawat, awak pesawat, muatan barang pesawat yang biasa disebut kargo, maupun penumpang pesawat, dan yurisdiksi atas itu, yang bertujuan untuk menerapkan atau mempraktekkan ke dalam penegakan hukum pidana secara umum dan secara khususnya untuk melindungi penerbangan sipil internasional. ${ }^{19}$

Konvensi Internasional khususnya konvensi-konvensi penerbangan internasional selalu digunakan sebagai acuan atau pedoman bagi penyusunan perundang-undangan nasional. Sebagaimana Konvensi Chicago 1944 yang merupakan aturan dasar di dalam penerbangan sipil internasional. Konvensi Chicago 1944 menjadi pedoman di dalam penyusunan aturan hukum nasional khususnya bagi tiap-tiap negara anggota Organisasi Penerbangan Sipil Internasional (Internasional Civil Aviation Organization selanjutnya disebut ICAO) dalam menyelenggarakan hukum penerbangan sipil internasional. ${ }^{20}$ Negara Indonesia pun sebagai salah satu negara anggota ICAO. ICAO merupakan suatu badan organisasi yang eksistensinya dinaungi oleh Perserikatan Bangsa-Bangsa (PBB). Badan organisasi ini dibentuk dengan tujuan untuk meningkatkan dan memajukan dasar-dasar sarana pandu arah (navigation) khususnya pandu arah (navigation) udara internasional, dan selain itu ikut berperan dalam memberikan bantuan demi berkembangnya suatu perencanaan dan demi berkembangnya angkutan udara internasional agar perkembangan angkutan udara akan terjamin sesuai dengan rencana dan berjalan dengan aman. ${ }^{21}$ Mengingat Negara Indonesia sebagai anggota ICAO, tentunya juga mengusung Konvensi Chicago 1944 khususnya yang dituangkan dalam Pasal 5 UU Penerbangan yang menegaskan bahwa Negara Indonesia berkedaulatan secara utuh menyeluruh dan sepenuhnya mutlak di atas wilayah ruang udara Republik Indonesia, yakni yang berada di atas wilayah permukaan daratan dan permukaan perairan Indonesia. Selanjutnya di dalam Pasal 6 UU Penerbangan, menyatakan untuk dapat menyelenggarakan sepenuhnya kedaulatan mutlak yang dimiliki negara atas ruang udara wilayahnya, khususnya di ruang udara wilayah Negara Indonesia,Pemerintah mempunyai kewenangan sekaligus berkapasitas selaku pihak yang dapat dimintai pertanggungjawaban perihal adanya kaidah terhadap ruang udara yang digunakan untuk mencapai tujuan kepentingan wilayah udara yakni di bidang penerbangan, ekonomi nasional, ketahanan dan keamanan negara, sosial budaya serta lingkungan udara.

Kedaulatan Negara Indonesia mempunyai hak yang sepenuhnya tertutup, disamping mempunyai sifat yang penuh utuh dan menyeluruh secara eksklusif (complete and exclusive). Sifat tertutup sepenuhnya di dalam hal ini dimaksudkan bahwa wilayah ruang udara suatu negara bersifat tertutup rapat bagi seluruh pesawat asing atau pesawat udara milik Negara lain baik sipil maupun militer, sehingga untuk dapat dilakukannya penerbangaan yang melewati atau memasuki ruang udara nasional bagi Pesawat udara asing harus mengajukan izin terlebih dahulu baik izin itu dilakukan melalui perjanjian multilateral maupun bilateral dari Negara yang wilayahnya dimasuki. Pemanfaatan dan pengelolaan atas wilayah ruang

18 Darwis, N. (2018). "Politik Hukum Memanfaatkan Wilayah Udara Untuk Kepentingan Penerbangan Di Wilayah Kedaulatan NKRI”. Jurnal Ilmiah Hukum Dirgantara, $6 \quad$ (1): 1-18, DOI: https://doi.org/10.35968/jh.v6i1.111, h. 8.

19 Hajaruman, A. N. (2015). "Penegakan Hukum Terhadap Pesawat Militer Asing Yang Diterbangkan Dari Kapal Induk Saat Melintas Alur Laut Kepulauan Indonesia (ALKI)". Perspektif Hukum, 15 (1): 45-67, DOI: http://dx.doi.org/10.30649/phj.v15i1.23, h. 66.

${ }^{20}$ Manullang, Y. N., Widodo, H., \& Angwarmasse, P. Y. (2019). “Aspek Hukum Internasional Terhadap Yurisdiksi Dalam Mengadili Pelaku Pembajakan Pesawat Udara”. Krisna Law, 1 (3): 109-128, h. 111.

21 Ibid, h. 112. 
udara kepunyaan setiap Negara mutlak merupakan hak yang utuh menyeluruh dan sepenuhnya lengkap dari negara yang wilayahnya dimasuki atau yang dikenal dengan istilah Negara kolong. ${ }^{22}$

Aturan mengenai ruang udara nasional bersifat tertutup, pertama kali dibuat pengaturannya di dalam Undang-Undang Nomor 83 Tahun 1958 Tentang Penerbangan, meskipun di dalamnya tidak mengatur terkait dengan kepemilikan hak kedaulatan bagi negara Indonesia atas ruang udara wilayahnya, tetapi justru menyatakan mengenai adanya larangan untuk dilakukannya penerbbangan, kecuali penerbangan yang dimaksud dilakukan dengan pesawat udara berkebangsaan Indonesia, atau dapat juga dilakukannya penerbangan bagi pesawat udara asing apabila sebelumnya telah ada perjanjian internasional atau adanya persetujuan dari pemerintah. Hal ini sejalan dengan Pasal 6 Konvensi Chicago 1944 yang pada dasarnya sengaja diusung oleh Negara Indonesia, yakni bahwa untuk dilakukannya penerbangan yang melintasi Negara lain oleh pesawat asing, wajib atau mengharuskan adanya izin yang ditujukan bagi negara kolong, yang wilayahnya dilintasi atau dimasuki.

Adanya ketetapan mengenai sifat tertutup yang dimaksud dalam hal ruang udara, khususnya di lingkup nasional menjadi alasan karena ruang udara suatu Negara dianggap sebagai sarana dalam bermobilitas yang apabila dilihat dari sisi ketahanan dan keamanan suatu Negara, merupakan hal yang sangat beresiko akan timbulnya gangguan dan bahaya. Gangguan dan bahaya yang dimaksud merupakan pelanggaran dalam wilayah udara. Pelanggaran yang dimaksud bentuknya dapat berupa tindakan penyerangan secara militer misalnya mengenai kesigapan (speed), jarak tempuh (range), serangan secara mendadak (surprise), penerobosan (penetration) dapat dilalui secara sempurna meskipun pelaksanaannya hanya dengan melalui media udara yakni dengan pesawat udara. Hal-hal inilah yang mendesak atau memaksa untuk setiap Negara berupaya melakukan pengamanan secara maksimal dan ketat terhadap wilayah udara nasionalnya.

\section{Yurisdiksi Kriminal Di Ruang Udara Wilayah Indonesia Terhadap Black Flight}

Mengingat luasnya ruang udara wilayah Indonesia, hal tersebut seringkali dijadikan kesempatan bagi pesawat asing untuk membuat suatu tindakan yang sifatnya merupakan gangguan dan bahaya yang dimaksudkan sebagai pelanggaran dalam wilayah udara. Pelanggaran dalam wilayah udara di dalam UU Penerbangan menggunakan istilah lain yakni pelanggaran wilayah kedaulatan, terutama bagi tindakan pesawat asing yang melanggar kedaulatan ruang udara dengan cara masuk dan melewati ruang udara wilayah kedaulatan milik Negara Indonesia tidak dengan disertai dokumen izin, sesuai yang diatur dalam Penjelasan Pasal 8 ayat (1) UU Penerbangan.

Pelanggaran wilayah kedaulatan yang dimaksud di atas, dikenal pula dengan istilah penerbangan gelap (black flight). Pada dasarnya ada kategori untuk dapat mengklasifikasikan suatu pesawat udara asing melakukan tindakan blackflight. Black flight merupakan situasi dimana pesawat asing baik itu yang berjenis pesawat sipil maupun termasuk juga yang berjenis pesawat militer yang terbang melewati atau memasuki wilayah udara Negara lain dalam hal ini khususnya wilayah udara Indonesia dengan tidak menyertakan dokumen izin terbang yang diperoleh dari pihak yang berwenang mengawasi jalannya lalu lintas udara Air Traffic Controller (ATC) Negara kolong sesuai yang diatur dalam UU Penerbangan. Sehingga pesawat asing yang dimaksudkan tersebut tidak masuk ke daftar penerbangan terjadwal di dalam daftar rencanaa penerbangan Flight Clearance

22 Apriadi, A. (2019). "Kedudukan Hubungan Diplomatik Antar Negara Dalam Perizinan Hak Lintas Terbang Atas Negara Lain”. Dinamika Hukum, 25 (12): 1-8, h. 3. 
Information System (FCIS). ${ }^{23}$ Hal ini yang membuat penerbangan tersebut dikategorikan sebagai Black flight.

Tindakan black flight dianggap sebagai bentuk ancaman nyata terhadap kedaulatan negara karena sudah jelas merupakan pelanggaran terhadap keamanan wilayah udara Negara Kesatuan Republik Indonesia khususnya apabila tindakan black flight dilakukan dengan maksud mengancam pertahanan Negara, baik dilakukan dengan tindakan permusuhan (Hostile Act) maupun tindakan niat permusuhan (Hostile Intent). ${ }^{24}$ Dikatakan sebagai ancaman selain karena melanggar hak kedaulatan di wilayah udara Negara Indonesia, adanya black flight yang diperbuat oleh pesawat-pesawat asing tersebut beresiko memunculkan ancaman lainnya, misalnya berupa tindakan pengintaian atau memata-matai sesuatu yang dianggap sebagai objek penting dari suatu Negara untuk mendapatkan informasi terkait militer sebagai tindakan yang illegal, ${ }^{25}$ tindakan pengrusakan atau sabotase dan tindakan mencemari dan merusak lingkungan khususnya wilayah udara. ${ }^{26}$ Sehigga dikhawatirkan adanya tindakan yang menyalahgunakan wilayah udara demi tercapainya suatu kepentingan Negara tertentu untuk merealisasikan kehendaknya, atau hanya bertujuan untuk menjadikannya sebagai jalan pintas yang akan dilewati. ${ }^{27}$

Negara Indonesia dikenal sebagai Negara kepulauan, dikarenakan wilayahnya amat sangat luas dan terdiri dari begitu banyak pulau. Sehingga dalam penjagaan ketahanan dan keamanan khususnya di wilayah udara, bukanlah merupakan perkara yang mudah. ${ }^{28}$ Untuk membantu memudahkan dalam melakukan penjagaan terhadap ketahanan dan kemanan wilayah udara suatu Negara, diperlukan sistem pertahanan dan keamanan yang kuat, tujuannya tidak lain adalah untuk merealisasikan wilayah udara Indonesia yang aman dan kuat. Negara Indonesia khususnya dalam wilayah udara, memiliki aparat yakni barisan TNIAU (Tentara Nasional Indonesia Angkatan Udara) yang bertugas dan mempunyai kewenangan yang pengaturannya terdapat dalam Pasal 10 Undang-Undang Nomor 34 Tahun 2004 tentang TNI yakni antara lain;

a) Menjalankan tugasnya sebagai TNI yang kaitannya sebagai TNI Matra Udara terutama dalam segi pertahanann udara wilayah udara Negara Indonesia;

b) Menjalankan penegakkan hukum yang tetap disertai dengan tindakan penjagaan keamanan, khususnya tepat diwilayah udara sebagai yurisdiksi nasional, sebagaimana ketetapan di dalam hukum nasionalnya dan hukum internasional yang telah disahkan;

c) Menjalankan tugasnya sebagai TNI kaitannya dalam hal pembentukan dan peningkatan kekuatan di bidang matra udara; dan

d) Menjalankan proses khususnya memberdayakan wilayah pertahanan udara.

TNI-AU di dalam menjalankan tugas dan wewenangnya didampingi oleh KOHANUDNAS (Komando Pertahanan Udara Nasional) yang perannya sebagai komando yang paling penting dan paling utama khususnya di dalam kekuatan Markas Besar TNI.

23 Barus, Y. J., Arif, A., \& Sutiarnoto, S. (2014). Op. Cit., h. 21.

24 Waas, R. M. (2016). "Penegakan Hukum Di Kawasan Alur Laut Kepulauan Indonesia (ALKI) Menurut Konsepsi Hukum Internasional Dan Hukum Nasional Indonesia". SASI, 22 (1): 22-36, DOI: https://doi.org/10.47268/sasi.v22i1.174, h. 27.

${ }_{25}$ Jannah, C. M., \& Tinianus, E. (2018). "Pengaturan Hukum Terhadap Lintas Pesawat Asing Di Atas Alur Laut Kepulauan Indonesia”. Jurnal Ilmiah Mahasiswa Bidang Hukum Kenegaraan, 2 (1), 137-149, h. 138.

26 Waas, R. M. (2016). Op. Cit., h. 29.

27 Risdiarto, D. (2019). "Kedaulatan Wilayah Udara Di Atas Alur Laut Kepulauan Indonesia (ALKI)". Jurnal Rechts Vinding: Media Pembinaan Hukum Nasional, 8 (2): 277-292, h. 281.

28 Setiani, B. (2018). "Konsep Kedaulatan Negara di Ruang Udara dan Upaya Penegakan Pelanggaran Kedaulatan oleh Pesawat Udara Asing”. Jurnal Konstitusi, $14 \quad$ (3): 489-510, DOI: https://doi.org/10.31078/jk1432, h. 491. 
KOHANUDNAS menjalankan fungsinya yakni bertindak sebagai mata dan telinga yang mengamati segala hal mengenai pergerakan pesawat udara yang melintasi wilayah Indonesia. Sehingga, diperlukan ALUTSISTA (Alat Utama Sistem Pertahanan) yang mempunyai kemampuan mumpuni untuk melaksanakan tugas penjagaan yang maksimal terhadap wilayah udara Indonesia, khususnya di kawasan-kawasan yang sering menjadi objek pelanggaran black flight, yakni kawasan-kawasan yang tidak termonitor oleh radar (black area) baik itu radar sipil maupun radar militer. Selain itu, pembuatan pengaturan hukum oleh suatu Negara terutama mengenai persoalan yang menyangkut keadaan yang aman dan selamat dalam berlalu lintas di ruang udara serta menyangkut pula pengamanan atas pesawat udara merupakan suatu hal yang utama. ${ }^{29}$

Sebagai bentuk penanggulangan adanya perbuatan yang termasuk dalam kategori pelanggaran hak kedaulatan wilayah ruang udara yang diperbuat oleh pesawat asing, Kementrian Perhubungan mengeluarkan Peraturan Menteri Perhubungan Nomor 109 Tahun 2016 Tentang Perubahan Atas Peraturan Menteri Perhubungan Republik Indonesia Nomor 66 Tahun 2015 Tentang Kegiatan Angkutan Udara Bukan Niaga Dan Angkutan Udara Niaga Tidak Berjadwal Luar Negeri Dengan Pesawat Udara Sipil Asing Ke Dan Dari Wilayah Negara Kesatuan Republik Indonesia (Peraturan Menteri Perhubungan 109/2016), yakni di dalam Pasal 7 ayat (1) yang menegaskan bahwa bagi seluruh pesawat udara asing yang jenisnya merupakan jenis pesawat udara negara maupun sipil yang berencana hendak melakukan penerbangan dengan memasuki atau melewati ataupun mendarat di wilayah Indonesia diwajibkan untuk mendapatkan izin terbang (flight clearance) dari Negara Indonesia. Izin penerbangan yang dimaksud dalam hal ini merupakan izin sebagaimana yang diatur dalam Pasal 1 angka 17 PeraturanMenteri Perhubungan 109/2016 yakni Izin terbang (flight clearance) perihal izin untuk memasuki atau melewati (overfliying), mendarat (landing) dan menginap (remain over night) di wilayah udara Negara Indonesia atau di bandar udara (bandara) di Indonesia yang sumber perizinannya diberikan oleh pemerintah Indonesia. Izin terbang (flight clearance) yang dikehendaki dan diberlakukan bagi pesawat udara asing diatur di dalam Pasal 7 ayat (2) Peraturan Menteri Perhubungan 109/2016 yang terdiri atas:

a) Diplomatic Clearance, yakni dokumen perizinan yang wujudnya tertulis yang diterbitkan Kementerian Luar Negeri Negara Kesatuan Republik Indonesia, berdasarkan dengan pertimbangan dari segi relasi politik dan diplomatik antar negara;

b) Security Clearance, yakni pada waktu atau periode tertentu yang diterbitkan oleh Markas Besar Tentara Nasional yang pertimbangannya berdasarkan faktor keamanan

c) Flight Approval, yakni merupakan kesepakatan yang diterbitkan untuk tujuan dilakukannya tindakan mengawasi dan mengendalikan mengenai persoalan pengangkutan (traffic rights) dan/atau persoalan pendayagunaan pesawat udaraoleh pejabat berwenang di sektor penerbangan sipil.

Bagi pesawat terbang yang jenisnya khusus pesawat kenegaraan, pejabat tinggi dan pemerintah asing serta pesawat terbang militer asing, bentuk izin terbang (flight clearance) yang diperlukan untuk memasuki wilayah udara Negara Indonesia hanya terdiri atas Diplomatik Clearance dan Security Clearance. ${ }^{30}$ Aturan mengenai diwajibkannya izin terbang tersebut bertujuan sebagai bentuk cara melakukan tindakan pengawasan dan pengamanan secara maksimal yang ditujukan bagi seluruh pesawat udara asing yang melalukan tindakan black flight dan usaha untuk mengantisipasi terhadap timbulnya

29 Risdiarto, D. (2018). "Penyidik Tni Angkatan Udara Dalam Kasus Pelanggaran Wilayah Udara Yurisdiksi Indonesia Oleh Pesawat Terbang Asing Tidak Terjadwal”. Jurnal Legislasi Indonesia, 14 (1): 77-89, h. 81 .

30 Jannah, C. M., \& Tinianus, E. (2018). Op. Cit., h. 140. 
ancaman yang diakibatkan oleh adanya black flight yang merupakan tindakan penerbangan illegal oleh pesawat asing. Mengingat Negara Indonesia adalah sebagai Negara yang berdaulat dan mempunyai kebebasan yang mutlak tidak boleh diintervensi ataupun dihalanghalangi, sehingga untuk dapat dilakukannya aktivitas melintasi atau memasuki wilayahudara Indonesia oleh pesawat asing haruslah dengan izin seperti yang dimaksud untuk menghindari tindakan black flight.

Negara Indonesia mempunyai yurisdiksi kriminal di ruang udara wilayah Indonesia dalam menangani tindakan pelanggaran black flight. Apabila telah terjadi pelanggaran black flight di wilayah udara Indonesia, dalam hal ini yang mempunyai wewenang untuk mengambil langkah penyelesaiannya adalah TNI-AU. Tindakan dalam hal yurisdikisi kriminal yang dimaksud sebgaimana diatur dalam Pasal 8 UU Penerbangan dan Pasal 31 hingga Pasal 38 Peraturan Pemerintah Nomor 4 Tahun 2018 Tentang Pengamanan Wilayah Udara Republik Indonesia, yang juga mengadopsi ketentuan di Pasal 3 bis Konvensi Chicago 1944 mengenai prosedur tindakan bagi pesawat asing yang melakukan pelanggaran kedaulatan khususnya black flight, antara lain sebagai berikut: ${ }^{31}$

1) Tindakan Peringatan. Terhadap pesawat asing yang melakukan tindakan black flight, pertama dilakukan terlebih dahulu peringatan yang ditujukan bagi pesawat asing yang melakukan pelanggaran. Peringatan bagi pesawat asing yang dimaksud bertujuan untuk memastikan yang peringatannya diberikan dengan melalui media komunikasi berupa radiotelepon dengan gelombang siaran "darurat" yaitu pengaturan frekuensinya 121.500 Megahertz (MHz) atau frekuensi 243.000 Megahertz (MHz) yang dalam memfungsikannya diatur dalam Mode Alpha (A) dengan dibarengi Squawk 7700 dalam Mode C (Charlie) jika diperlengkap dengan transmitter responder yang menginfokan bahwa pesawat asing yang bersangkutan melakukan pelanggaran yakni melampaui batas wilayah udara Negara Indonesia, untuk kemudian menginstruksikan untuk segera pergi meninggalkan wilayah udara Indonesia. ${ }^{32}$ Peringatan ini bertujuan untuk memastikan adanya dokumen izin penerbangan (flight clearance) yang dimaksudkan. Dalam hal ini satuan radar (satrad) yang letak wilayahnya terpencar di seluruh Indonesia dan Air Traffic Controller (ATC) yang terletak di pangkalan udara atau bandar udara sebagai bagian dari anggota lalu lintas udara sekaligus memberikan informasi kepada aparat yakni TNI-AU mengenai adanya pesawat udara asing yang melakukan perbuatan yang dapat dimasukkan dalam kategori pelanggaran di wilayah udara berupa black flight.

2) Tindakan Membayang-Membayangi (Shadowing). Apabila tindakan berupa memberikan peringatan melalui media komunikasi radiotelepon gagal untuk dipatuhi oleh pesawat asing yang melakukan pelanggaran di wilayah udara berupa black flight. Alih-alih mematuhi, pesawat asing yang melakukan pelanggaran black fight tersebut justru melanjutkan penerbangannya. Dalam kondisi seperti ini, tindakan selanjutnya yakni melakukan tindakan membayang-bayangi (shadowing) terhadap pesawat asing yang melanggar kedaulatan wilayah udara. Tindakan membayang-bayangi ini dilakukan apabila pesawat asing terindikasi akan melakukan aktivitas yang mencurigakan di atas wilayah yurisdiksi dengan melampaui jalur yang sudah menyimpang. Tindakan membayang-bayangi ini dilakukan dengan menggunakan

31 Risdiarto, D. (2016). "Penegakan Hukum Terhadap Pelanggaran Wilayah Udara Yurisdiksi Indonesia Oleh Pesawat Terbang Asing Tidak Terjadwal”. Jurnal Rechts Vinding: Media Pembinaan Hukum Nasional, 5 (1): 69-82, h. 71.

32 Purwanto, R. (2017). Efektivitas Tindakan Forcedown Terhadap Black Flight Sebagai Upaya Penegakan Hukum Udara Di Indonesia. Skripsi: Fakultas Hukum Universitas Hasanuddin Makassar, h. 62. 
pesawat udara TNI-AU, disertai tindakan yang dilakukan dengan cara pengidentifikasian secara visual;

3) Tindakan Menghalau (Intervention). Apabila dalam melakukan tindakan membayangbayangi yang dilakukan oleh TNI-AU seperti di atas gagal ditaati oleh pesawat asing yang melakukan pelanggaran di wilayah udara berupa black flight, maka untuk selanjutnya pesawat tempur TNI-AU melakukan tindakan berupa menghalau pesawat asing tersebut agar segera keluar dan segera pergi meninggalkan wilayah udara Indonesia.

4) Tindakan Pemaksaan untuk Melakukan Pendaratan (Force Down). Tindakan berupa pemaksaan untuk melakukan pendaratan ini dilakukan dalam hal apabila pesawat asing yang melakukan pelanggaran di wilayah udara berupa black flight menunjukkan adanya indikasi bahwa pesawat asing tersebut akan melakukan aktivitas yang mencurigakan berupa ancaman terhadap keamanan wilayah udara Indonesia. Tindakan pemaksaan untuk melakukan pendaratan ini dilakukan apabila tindakan berupa peringatan hingga tindakan menghalau gagal untuk dipatuhi pesawat asing yang bersangkutan. Pendaratan secara paksa dilakukan tepatnya kawasan yang menjangkau pangkalan udara (lanud) atau bandar udara (bandara) terdekat.

5) Tindakan Penghancuran (Destruction). Tindakan penghancuran atas pesawat asing yang melakukan perbuatan yang masuk kategori pelanggaran di wilayah udara berupa black flight ini dilakukan oleh pesawat tempur TNI-AU milik Indonesia dengan cara melakukan penembakan, apabila memang pesawat asing tersebut menolak untuk mematuhi peringatan dan arahan dari aparat yang berwenang mewakili negara yang dilanggar dalam hal ini TNI-AU. Hal ini dikarenakan pesawat asing yang bersangkutan melakukan aktivitas yang memberikan ancaman terhadap suatu hal yang dianggap penting di wilayah Negara kolong atau pada saat pesawat tempur TNI-AU milik Indonesia melakukan penghalauan, pesawat asing menunjukkan tanda-tanda yang gerak-geriknya bersifat membahayakan.

6) Tindakan Nota Protes Diplomatik. Nota protes diplomatik yang dimaksud dalam hal ini wujudnya berupa surat yang ditujukan kepada Negara yang melanggar oleh pemeritah Indonesia, yang pada intinya secara resmi menyampaikan atau memberitahukan adanya bentuk pelanggaran yang telah dilakukan oleh Negara terkait pesawat asing berbendara Negara tersebut. Cara ini dinilai lebih ampuh karena hal ini dinilai sebagai sanksi dan sekaligus menjatuhkan kredibiltas bagi Negara bendera pesawat akibat melakukan pelanggaran hukum berupa black flight. ${ }^{33}$

Negara Indonesia, dalam menjalankan yurisdiksi kriminal di ruang udara wilayahnya terhadap pesawat asing yang melakukan pelanggaran black flight tentu saja tidak mengabaikan aturan dalam Pasal 3 bis Konvensi Chicago 1944, mengenai kewajiban dengan memperhatikan prinsip mengutamakan keselamatan penumpang sipil di dalam pesawat yang bersangkutan, selain itu pula tetap harus memperhatikan awak pesawat dan barang angkutan yang berada di dalam pesawat tersebut. ${ }^{34}$ Sehingga segala tindakan yang dilakukan Negara Indonesia terhadap pesawat asing sebisa mungkin tidak akan menimbulkan sesuatu yang membahayakan khususnya jiwa manusia baik awak pesawat maupun penumpang pesawat itu sendiri. TNI-AU terlebih dahulu memulai dengan tindakan yang lebih ringan yakni memerintahkan pesawat asing untuk segera keluar dan seger pergi meninggalkan wilayah udara Indonesia, hingga pada tindakan yang lebih berat dalam hal pesawat asing gagal

33 Clorinda, J. I. U., Santoso, M. I., \& Widodo, H. (2019). Op. Cit., h. 83.

34 Widarto, B. (2017). "Pertanggungjawaban Hukum Dalam Penembakan Pesawat Udara Sipil Ditinjau Dari Aspek Hukum Internasional”. Jurnal Yuridis, 1 (2): 141-152, DOI: http://dx.doi.org/10.35586/.v1i2.147, h. 145 . 
mematuhi seperti melakukan pemaksaan untuk mendarat (force down) atau dilakukannya penembakan apabila tetap menolak arahan TNI-AU. Selanjutnya mengenai penyidikan akan dilakukan oleh Markas Besar TNI yang untuk kemudian diberikan sanksi oleh Dinas Perhubungan. Semua dilakukan atas dasar yurisdiksi dan kedaulatan Indonesia sebagai bentuk untuk mengantisipasi terhadap timbulnya ancaman yang diakibatkan oleh adanya blackflight yang merupakan tindakan penerbangan illegal oleh pesawat asing

\section{P E N U T U}

Berdasarkan uraian yang disebutkan di atas, dapat disimpulkan bahwa kedaulatan Negara Indonesia atas batas wilayah ruang udara nasionalnya, mempunyai sifat penuh dan eksklusif sebagaimana yang diatur dalam Pasal 5 UU Penerbangan. Disamping mempunyai kedaulatan yang penuh dan eksklusif, kedaulatan Negara Indonesia mempunyai hak yang sepenuhnya tertutup, yakni bahwa wilayah ruang udara nasional tertutup rapat bagi pesawat asing atau pesawat udara milik Negara lain baik sipil maupun militer, sehingga terdapat larangan dilakukannya penerbangan bagi pesawat udara asing kecuali sebelumnya terdapat perjanjian internasional baik melalui perjanjian multilateral maupun bilateral dari Negara Indonesia atau mengharuskan adanya izin persetujuan dari pemerintah. Black flight merupakan bentuk ancaman nyata terhadap kedaulatan Negara, dimana pesawat asing terbang memasuki wilayah udara Indonesia dengan tidak menyertakan izin terbang sehingga tidak masuk ke daftar rencana penerbangan Flight Clearance Information System. Yurisdiksi kriminal di ruang udara wilayah Indonesia terhadap black flight dilakukan oleh TNI-AU dengan diawali tindakan yang lebih ringan berupa tindakan peringatan yang memerintahkan pesawat asing untuk segera keluar dan segera pergi meninggalkan wilayah udara Indonesia, hingga pada tindakan yang lebih berat yakni melakukan pemaksaan untuk mendarat (force down) atau dilakukan penembakan apabila tetap menolak arahan TNI-AU dengan tidak mengabaikan aturan dalam Pasal 3 bis Konvensi Chicago1944 mengenai keselamatan para penumpang atau awak pesawat. Juga dapat dilakukan dengan nota protes diplomatic yakni menyampaikan adanya pelanggaran black flight yang dilakukan pesawat asing berbendara Negara yang bersangkutan.

\section{DAFTAR PUSTAKA}

\section{Jurnal}

[1] Apriadi, A. (2019). Kedudukan Hubungan Diplomatik Antar Negara Dalam Perizinan Hak Lintas Terbang Atas Negara Lain. Dinamika Hukum, 25 (12): 1-8.

[2] Barus, Y. J., Arif, A., \& Sutiarnoto, S. (2014). Yurisdiksi Wilayah Udara Suatu Negara Dalam Perspektif Hukum Internasional. Sumatra Journal of International Law, 2 (1): $1-23$.

[3] Batubuaja, V. T. P. (2016). Penataan Ruang Di Indonesia Dilihat Dari Aspek Pengusaan Ruang Udara Menurut Peraturan Pemerintah Nomor 26 Tahun 2008 Tentang Rencana Tata Ruang Wilayah Nasional. Lex Et Societatis, 4 (2.1): 87-93.

[4] Ciptantri, S. B., Mangku, D. G. S., \& Yuliartini, N. P. R. (2020). Pertanggungjawaban Negara Uni Soviet Atas Penembakan Pesawat Korea Air Lines Ditinjau Dari Perspektif Hukum Udara Internasional. Jurnal Komunitas Yustisia, 1 (3): 41-50.

[5] Clorinda, J. I. U., Santoso, M. I., \& Widodo, H. (2019). Pelanggaran Hak Lintas Navigasi Oleh Pesawat Asing Di Ruang Udara Teritorial Indonesia. Krisna Law, 1 (3): 77-86.

[6] Daming, S. (2014). Telaah Perwujudan Kedaulatan Negara Atas Wilayah Udara Dalam 
Persfektif Hukum. Yustisi, 1 (2): 23-41.

[7] Darwis, N. (2018). Politik Hukum Memanfaatkan Wilayah Udara Untuk Kepentingan Penerbangan Di Wilayah Kedaulatan NKRI. Jurnal Ilmiah Hukum Dirgantara, 6 (1): 1-18, DOI: https://doi.org/10.35968/jh.v6il.111.

[8] Hajaruman, A. N. (2015). Penegakan Hukum Terhadap Pesawat Militer Asing Yang Diterbangkan Dari Kapal Induk Saat Melintas Alur Laut Kepulauan Indonesia (ALKI). Perspektif Hukum, $15 \quad$ (1): 45-67, DOI: http://dx.doi.org/10.30649/phj.v15i1.23.

[9] Jannah, C. M., \& Tinianus, E. (2018). Pengaturan Hukum Terhadap Lintas Pesawat Asing Di Atas Alur Laut Kepulauan Indonesia. Jurnal Ilmiah Mahasiswa Bidang Hukum Kenegaraan, 2 (1): 137-149.

[10] Mangku, D. G. S., \& Radiasta, I. K. (2019). Tanggung Jawab Negara terhadap Penembakan Pesawat MH17 berdasarkan Hukum Internasional. Pandecta: Research Law Journal, 14 (1): 25-33, DOI: https://doi.org/10.15294/pandecta.v14i1.18987.

[11] Manullang, Y. N., Widodo, H., \& Angwarmasse, P. Y. (2019). Aspek Hukum Internasional Terhadap Yurisdiksi Dalam Mengadili Pelaku Pembajakan Pesawat Udara. Krisna Law, 1 (3): 109-128.

[12] Risdiarto, D. (2016). Penegakan Hukum Terhadap Pelanggaran Wilayah Udara Yurisdiksi Indonesia Oleh Pesawat Terbang Asing Tidak Terjadwal. Jurnal Rechts Vinding: Media Pembinaan Hukum Nasional, 5 (1): 69-82.

[13] Risdiarto, D. (2018). Penyidik Tni Angkatan Udara Dalam Kasus Pelanggaran Wilayah Udara Yurisdiksi Indonesia Oleh Pesawat Terbang Asing Tidak Terjadwal. Jurnal Legislasi Indonesia, 14 (1): 77-89.

[14] Risdiarto, D. (2019). Kedaulatan Wilayah Udara Di Atas Alur Laut Kepulauan Indonesia (ALKI). Jurnal Rechts Vinding: Media Pembinaan Hukum Nasional, 8 (2): 277-292.

[15] Riyanto, S. (2012). Kedaulatan Negara Dalam Kerangka Hukum Internasional Kontemporer. Yustisia Jurnal Hukum, 1 (3): DOI: https://doi.org/10.20961/yustisia.vli3.10074.

[16] Sefriani, S. (2015). Pelanggaran Ruang Udara oleh Pesawat Asing Menurut Hukum Internasional dan Hukum Nasional Indonesia. Jurnal Hukum Ius Quia Iustum, 22 (4): 538-565, DOI: https://doi.org/10.20885/iustum.vol22.iss4.art2.

[17] Setiani, B. (2018). Konsep Kedaulatan Negara di Ruang Udara dan Upaya Penegakan Pelanggaran Kedaulatan oleh Pesawat Udara Asing. Jurnal Konstitusi, 14 (3): 489-510, DOI: https://doi.org/10.31078/jk1432.

[18] Waas, R. M. (2016). Penegakan Hukum Di Kawasan Alur Laut Kepulauan Indonesia (ALKI) Menurut Konsepsi Hukum Internasional Dan Hukum Nasional Indonesia. SASI, 22(1): 22-36, DOI: https://doi.org/10.47268/sasi.v22i1.174.

[19] Widarto, B. (2017). Pertanggungjawaban Hukum Dalam Penembakan Pesawat Udara Sipil Ditinjau Dari Aspek Hukum Internasional. Jurnal Yuridis, 1 (2): 141-152, DOI: http://dx.doi.org/10.35586/.v1i2.147.

[20] Yudhistira, A. (2018). Over-the-Horizon Radar (Othr) Untuk Menjaga Wilayah Udara Dan Laut Indonesia. Jurnal Pertahanan \& Bela Negara, 5 (2): 133-148, DOI: http://dx.doi.org/10.33172/jpbh.v5i2.361

\section{Skripsi}

[21] Purwanto, R. (2017). Efektivitas Tindakan Forcedown Terhadap Black Flight Sebagai Upaya Penegakan Hukum Udara Di Indonesia. Skripsi: Fakultas Hukum Universitas Hasanuddin Makassar. 


\section{Buku}

[22] Hadiwijoyo, S.S. (2011). Perbatasan Negara Dalam Dimensi Hukum Internasional, Yogyakarta: Graha Ilmu.

[23] Kusumaatmadja, M. (2010). Pengantar HukumInternasional: Buku I Bagian Umum, Jakarta: Bina Cipta.

[24] Sitepu, P.A. (2011). Studi Hubungan Internasional, Yogyakarta: Graha Ilmu.

[25] Sefriani, S. (2016). Hukum Internasional Suatu Pengantar Edisi Kedua, Jakarta: Raja Grafindo Persada.

[26] Yulianingsih, W., \& Sholihin, M.F. (2014). Hukum Organisasi Internasional, Yogyakarta: Penerbit Andi. 